\title{
Activin A and activin receptors in gestational tissue from preeclamptic pregnancies
}

\author{
U Manuelpillai, M Schneider-Kolsky, A Dole and E M Wallace
}

Centre for Women's Health Research, Department of Obstetrics and Gynaecology, Monash University, Clayton, Victoria, Australia

(Requests for offprints should be addressed to U Manuelpillai, Centre for Women's Health Research, Department of Obstetrics and Gynaecology, Monash University, Monash Medical Centre, 246 Clayton Road, Clayton, Victoria 3168, Australia; Email: Ursula.Manuelpillai@med.monash.edu.au)

\begin{abstract}
Maternal serum activin A levels are elevated in women with preeclampsia. To explore whether this could be due, at least in part, to increased production by the gestational tissues, we have measured activin $\mathrm{A}$ in the serum of women with $(n=23)$ or without preeclampsia $(n=62)$ at 29-40 weeks of gestation and in placenta and fetal membranes from preterm preeclamptic (PT-PE, $n=8)$, term preeclamptic (T-PE, $n=10)$ and healthy term controls $(\mathrm{T}-\mathrm{C}, n=10)$. We have also explored if there are associated changes in activin receptor Alk2, ActRII and ActRIIB in these tissues. The relative amounts of receptor proteins were measured by densitometry on Western blots and receptors and activin $\beta_{\mathrm{A}}$ subunit localised by immunohistochemistry in PT-PE, T-PE and T-C gestational tissues ( $n=8-10$ /group).

Maternal serum activin A levels were significantly elevated in women with preeclampsia (multiples of the normal median $(\mathrm{MoM})=3 \cdot 5, P<0 \cdot 0001$, Mann-Whitney $\mathrm{U}$ test) compared with healthy women (median MoM=1·0). Compared with control tissues, the activin A content was significantly higher in preeclamptic placentae $(P=0.001$ and $P=0.0005$ for PT-PE and T-PE respectively, Mann-Whitney U test), but significantly lower in
\end{abstract}

the amnion $(P=0 \cdot 005$ and $P=0 \cdot 014$ for PT-PE and T-PE respectively) and choriodecidua ( $P=0.009$ for T-PE). The maternal serum activin A level in women with preeclampsia was significantly correlated with elevated placental production $(P=0 \cdot 01$, Pearson's correlation). Receptor Alk2 protein levels were significantly elevated in T-PE placentae $(P=0 \cdot 0006$, Mann-Whitney $U$ test $)$, ActRIIB levels were significantly lower in PT-PE placentae $(P=0 \cdot 01)$ and ActRII levels were significantly lower in PT-PE choriodecidua $(P=0.0002)$ compared with controls. There were no apparent differences in the distribution of the $\beta_{\mathrm{A}}$ subunit and receptors Alk2, ActRII and ActRIIB between control and preeclamptic tissues.

These findings suggest that elevated levels of activin A in the maternal circulation in association with preeclampsia are due, at least in part, to increased placental production, and that the regulation of activin synthesis in placenta and fetal membranes is differentially regulated. Further, the differences in activin receptor protein levels between preeclamptic and control placenta and choriodecidua suggest that activin A-induced regulation may be altered in preeclampsia.

Journal of Endocrinology (2001) 171, 57-64

\section{Introduction}

Activins are dimeric glycoproteins belonging to the transforming growth factor $\beta$ family that exert pleiotrophic effects on a wide variety of tissues (Massague 1990, Ying et al. 1997). Of the three activins - A, B and AB - that have been identified in human tissues, activin $\mathrm{A}$ is the predominant form in pregnancy (Qu \& Thomas 1995, Fowler et al. 1998). The placenta and fetal membranes are the main sources of circulating activin A (Rabinovici et al. 1992, Petraglia et al. 1997, Keelan et al. 1999). In early and mid pregnancy, maternal serum activin A levels are stable and low, rising dramatically from approximately 24 weeks of gestation, reaching peak levels proximate to term (Petraglia et al. 1993a, Fowler et al. 1998, Schneider-Kolsky et al. 2000). In preeclampsia, maternal serum activin A levels are significantly higher than those observed in gestation-matched normal pregnancies (Muttukrishna et al. 1997, 2000a, D'Antona et al. 2000). However, whether this is due to increased production in the placenta, fetal membranes and/or decreased clearance remains unexplored.

Activin A signal transduction is dependent upon the formation of a ligand receptor complex involving both a type II and a type I activin receptor (Attisano et al. 1996). mRNA for the activin receptors Alk2, ActRII and ActRIIB has been identified in the human placenta (Peng et al. 1999) and for ActRII and ActRIIB in the fetal membranes (Petraglia et al. 1997) but receptor protein localisation in these tissues has not been reported. It is also unknown whether the distribution and levels of receptor mRNA or protein are altered in gestational tissues in preeclampsia. 
We undertook this study to determine if there were differences in activin A production in gestational tissue in association with preeclampsia and whether tissue content was related to maternal serum activin A levels. We also studied the distribution and relative levels of activin receptor Alk2, ActRII and ActRIIB proteins in gestational tissue from healthy and preeclamptic women to explore potential differences in local regulation by activin A.

\section{Materials and Methods}

\section{Clinical details}

The control group consisted of healthy women with a normal, uncomplicated singleton pregnancy delivered at term (37-40 weeks of gestation) by elective Caesarean section for either breech presentation or previous Caesarean section. The women with preeclampsia were also delivered prior to labour by Caesarean section, preterm (29-35 weeks of gestation) or at term. Preeclampsia was diagnosed according to International Society for the Study of Hypertension in Pregnancy criteria (Perry \& Beevers 1994). There was no obvious intrauterine fetal growth restriction in any of the preeclamptic pregnancies, as defined by birth weight $<10$ th percentile for gestation. In all cases, the gestational age was calculated either by the last certain menstrual period or by an early pregnancy ultrasound. The study was approved by the Monash Medical Centre Human Research and Ethics Committee and informed, written consent was obtained from each patient.

\section{Activin A content in maternal serum and tissue lysates}

Blood samples were collected from the antecubital vein at 29-40 weeks of gestation (control $n=62$, preeclampsia $n=23$ ), centrifuged immediately at $3000 \mathrm{~g}$ for $15 \mathrm{~min}$ at $4{ }^{\circ} \mathrm{C}$ and the serum stored at $-20{ }^{\circ} \mathrm{C}$. Placenta and reflected fetal membranes were collected within $30 \mathrm{~min}$ of delivery from term control $(\mathrm{T}-\mathrm{C}, n=10)$, preterm preeclamptic (PT-PE, $n=8)$ and term preeclamptic women (T-PE, $n=10)$. The amnion was manually stripped from the choriodecidua, all tissues rinsed four to five times in sterile phosphate-buffered saline (PBS) solution, frozen in liquid nitrogen and stored at $-80{ }^{\circ} \mathrm{C}$. Frozen tissue was homogenised in cold sterile PBS with $0.05 \%$ Tween 20, centrifuged for $5 \mathrm{~min}$ at 13000 r.p.m. and supernatants stored at $-80{ }^{\circ} \mathrm{C}$. Total activin A in maternal serum and tissue lysates were measured by a specific two site enzymelinked immunosorbent assay (Knight et al. 1996), with minor modifications as described previously (Riley et al. 1998). Serum and placental tissue lysates were diluted 1:10 and lysates of the fetal membrane diluted 1:2 in assay diluent. The sensitivity of the assay was $72 \mathrm{pg} / \mathrm{ml}$ and the mean intra- and interassay coefficients of variation were $8 \%$ and $15 \%$ respectively.

\section{Protein assay}

The total protein concentration in tissue lysates was measured by the bicinchoninic acid method (Pierce, Rockford, IL, USA) calibrated against bovine serum albumin (BSA) standards ranging between 25 and $2000 \mu \mathrm{g} / \mathrm{ml}$.

\section{Activin receptor protein levels}

Fifteen micrograms of solubilised tissue protein (T-C, PT-PE and T-PE, $n=8-10$ per group) were separated on $10 \%$ polyacrylamide gels by SDS-PAGE and transferred onto nitrocellulose membranes. Non-specific binding was blocked with $1 \%$ gelatine and $0.02 \%$ Tween 20 in Tris-buffered saline and blots were incubated with polyclonal goat anti-human activin receptor Alk2, ActRII and ActRIIB antibodies $(0.3 \mu \mathrm{g} / \mathrm{ml} ; \mathrm{R} \& \mathrm{D}$ Systems, Minneapolis, MN, USA) for $1 \mathrm{~h}$ at room temperature. Immunoreactive protein was detected by applying horseradish peroxidase-conjugated rabbit anti-goat $\operatorname{IgG}(\mathrm{H}+\mathrm{L}$; 1:2000; Zymed, San Francisco, CA, USA) for $1 \mathrm{~h}$ at room temperature followed by 4-chloro-1-napthol. Secretory phase endometrium served as a positive control. The relative amount of immunoreactive protein was measured by densitometry (BioRad, Hercules, CA, USA) performed on the Western blot. Transfer efficiencies were checked by Coomassie blue staining of transferred gels and immunoreactive protein levels were standardised against the $81 \mathrm{kDa}$ BSA band of the prestained molecular weight marker (BioRad).

\section{$\beta_{A}$ subunit and activin receptor localisation}

Placenta and fetal membranes (T-C, PT-PE and T-PE, $n=8$ /group) were fixed in neutral buffered formalin for $12-16 \mathrm{~h}$ and embedded in paraffin. The endogenous peroxidase activity was inhibited with 3\% hydrogen peroxide in methanol for $15 \mathrm{~min}$ and non-specific binding blocked for $15 \mathrm{~min}$ with protein blocking agent (Dako, Carpinteria, CA, USA). Sections were incubated with primary antibodies $(2 \mu \mathrm{g} / \mathrm{ml}$ monoclonal mouse antihuman activin $\beta_{\mathrm{A}}$ subunit from N P Groome, Oxford Brookes University, Oxford, Oxon, UK and $1.5 \mu \mathrm{g} / \mathrm{ml}$ activin receptor Alk2, ActRII and ActRIIB from R \& D Systems) for $1 \mathrm{~h}$ at room temperature followed by incubation with biotinylated secondary antibodies $\left(\mathrm{LSAB}^{+}\right.$; Dako) for $15 \mathrm{~min}$ at room temperature. Immunostaining was detected by the addition of streptavidin-horseradish peroxidase conjugate and 3-amino 9-ethlcarbazole chromogen (Zymed). Sections were counterstained in haemotoxylin and mounted. For endothelial cell staining, serial sections of placenta were incubated with monoclonal mouse anti-human CD34 antibody (1:50; Serotec, Oxford, Oxon, UK) for $45 \mathrm{~min}$ at $37^{\circ} \mathrm{C}$ followed by alkaline phosphatase-conjugated secondary antibodies 


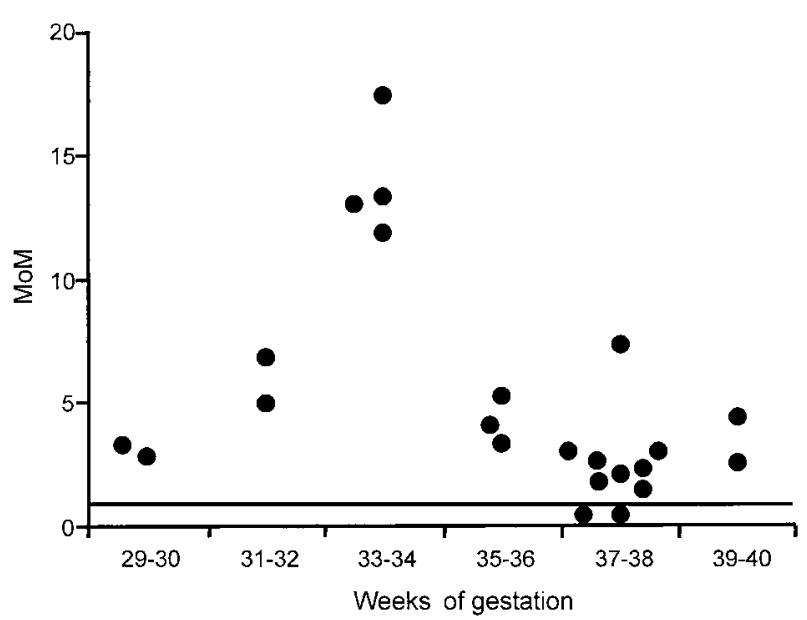

Figure 1 Total activin A levels in maternal serum of women with preeclampsia expressed as MoM. The horizontal line represents the median value of healthy pregnant women.

$\left(\mathrm{LSAB}^{+}\right.$; Dako) for $15 \mathrm{~min}$. Staining was visualised with Vector Blue (Vector Laboratories, Burlinghame, CA, USA). Negative and positive controls consisted of sections incubated with preimmune sera and secretory phase human endometrial biopsies respectively.

\section{Statistical analyses}

To correct for gestational-related changes, maternal serum activin A levels are expressed as multiples of the normal median (MoM) derived from the normal healthy controls. Differences in serum and tissue activin A content and receptor protein levels were assessed by the MannWhitney $U$ test. Correlations between serum and tissue activin A content were assessed by Pearson's linear correlation coefficient $(n=18)$. Significance was accorded when $P<0 \cdot 05$.

\section{Results}

Maternal serum activin A levels in women with preeclampsia are shown in Fig. 1. Overall, activin A levels were significantly elevated in women with preeclampsia compared with healthy pregnant women. The median (95\% confidence interval) activin A MoM values were 3.5 $(2 \cdot 6-5 \cdot 1)$ vs $1 \cdot 0(0 \cdot 9-1 \cdot 1)$ for the preeclamptic women and control groups respectively $(P<0 \cdot 0001$, Mann-Whitney U test).

Activin A was present in all placental, amnion and choriodecidual tissue lysates (Fig. 2). Placental total activin A content was significantly higher in PT-PE and T-PE tissue $(P=0.001$ and 0.0005 respectively, Mann-Whitney $\mathrm{U}$ test) compared with T-C placentae. Levels in PT-PE placentae were significantly higher compared with T-PE
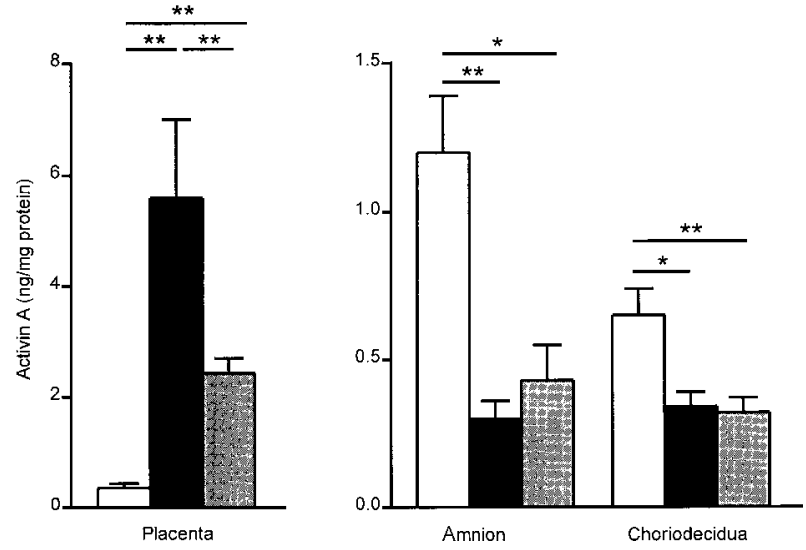

Figure 2 Mean \pm S.E.M. total activin A concentrations in gestational tissue from healthy T-C (open bars), PT-PE (solid bars) and T-PE (shaded bars) women. ${ }^{*} P<0 \cdot 05,{ }^{* *} P<0 \cdot 01$, Mann-Whitney $U$ test, $n=8-10$ /group.

placentae $(P=0 \cdot 002)$. In the amnion, however, the activin A content was significantly lower in both preeclamptic groups compared with T-C (PT-PE, $P=0 \cdot 005$; T-PE, $P=0 \cdot 014)$ with no significant difference between PT-PE and T-PE amnion. The choriodecidual activin A concentration was also significantly lower in T-PE tissue $(P=0 \cdot 009)$ compared with healthy women with no significant difference between the PT-PE and T-PE groups.

In 18 preeclamptic pregnancies where paired maternal serum and tissue samples were analysed (PT-PE, $n=8$; T-PE, $n=10)$, a significant positive correlation was found between serum and placental activin A content $(r=0 \cdot 84$ by Pearson's linear correlation, $P=0 \cdot 01)$.

The activin $\beta_{\mathrm{A}}$ subunit and receptor Alk2, ActRII and ActRIIB proteins were localised by immunohistochemistry in all sections of placenta and fetal membranes analysed. There were no apparent differences in the distribution of these proteins between healthy and preeclamptic tissue delivered at term or preterm (hence data for only the T-PE group are shown). The syncytiotrophoblast, cytotrophoblast and stromal cells stained positively for the $\beta_{\mathrm{A}}$ subunit in placentae with intense staining seen in the tissue of preeclamptic women compared with healthy controls (Fig. 3A and B). In the fetal membranes, the amniotic epithelial, fibroblast, reticular, chorionic trophoblast and adherent decidual cells showed positive staining for the $\beta_{\mathrm{A}}$ subunit (Fig. 3C and D). In positive control sections, the endometrial glandular epithelial cells stained intensely for the $\beta_{\mathrm{A}}$ subunit whereas staining was absent in the negative control sections (Fig. 3E and F). Activin receptor Alk2, ActRII and ActRIIB localised to similar cell types in the placenta and fetal membranes. Staining of low intensity was found in the cytotrophoblast cells of the placenta and sporadic staining was present in the syncytiotrophoblast layer (Fig. 3G and H). Intense staining for receptor Alk2, ActRII and ActRIIB was seen in the lining of fetal blood 

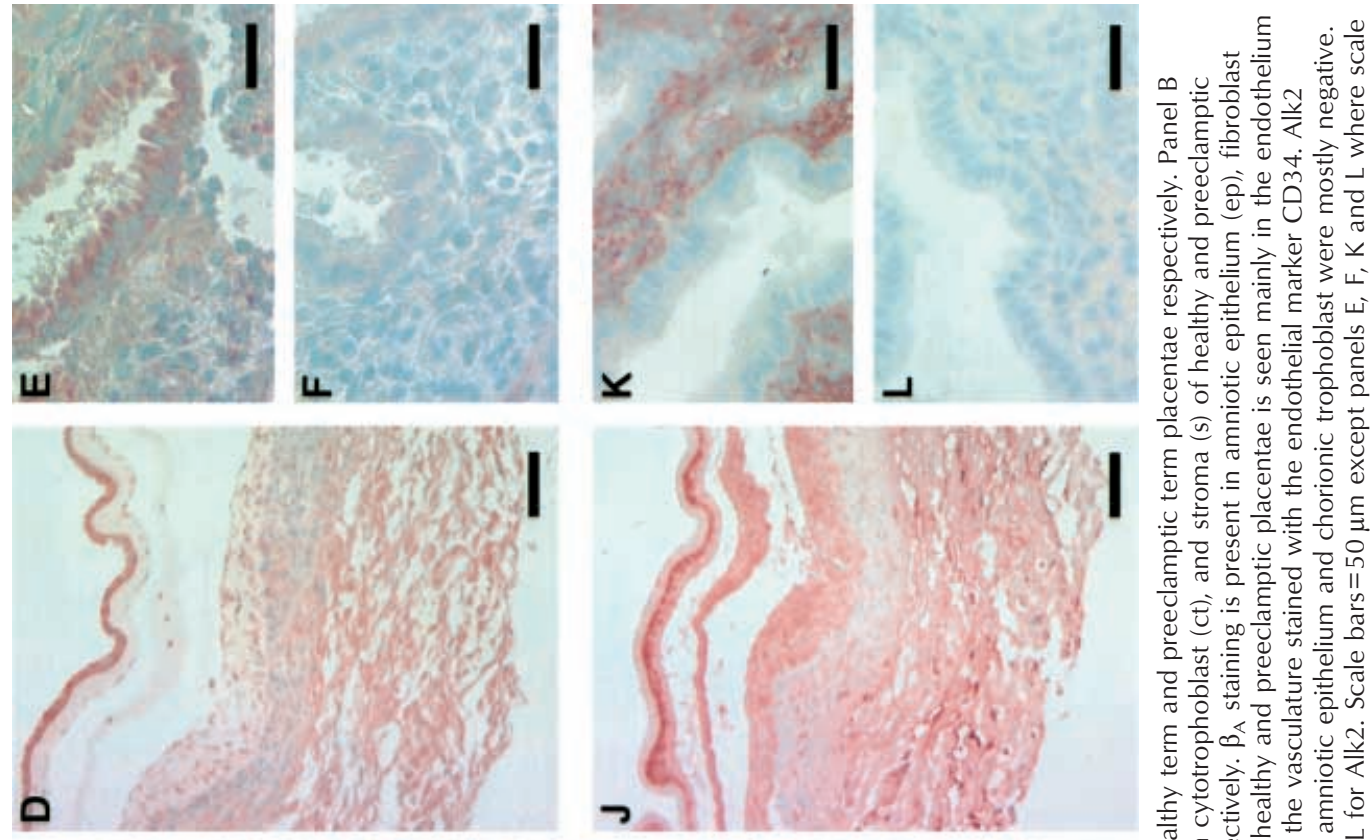

증

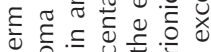

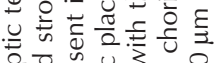

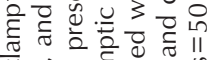

प्ष屯

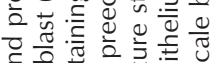

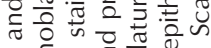

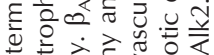

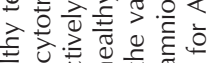
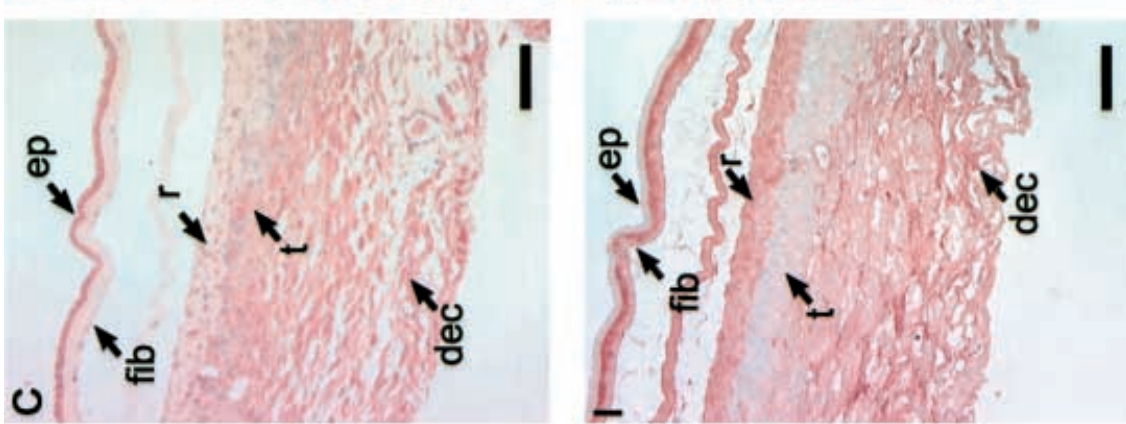

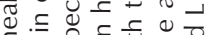
ᄃ ब

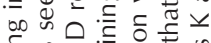

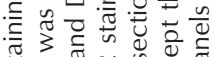
in 000 政 赵.

和要

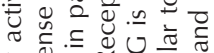
उ $\simeq \simeq$ हे

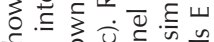
w w 0 $\infty$, w

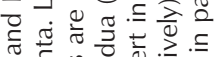
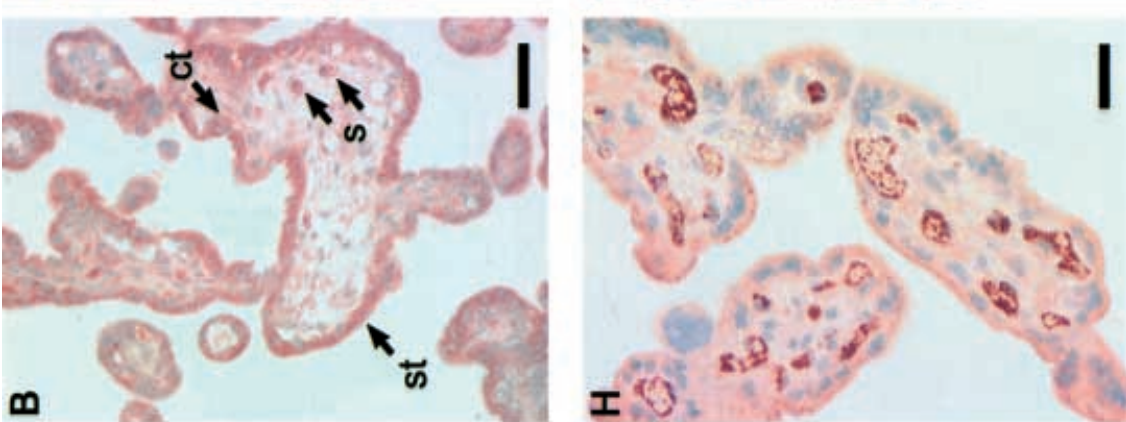
$<\bar{d} . \underline{Q}: \mathcal{U}$

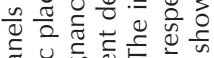
๘

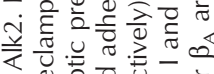

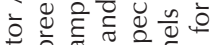

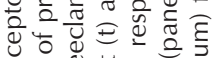

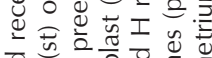

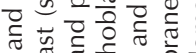

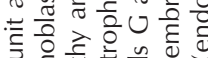

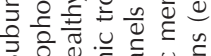
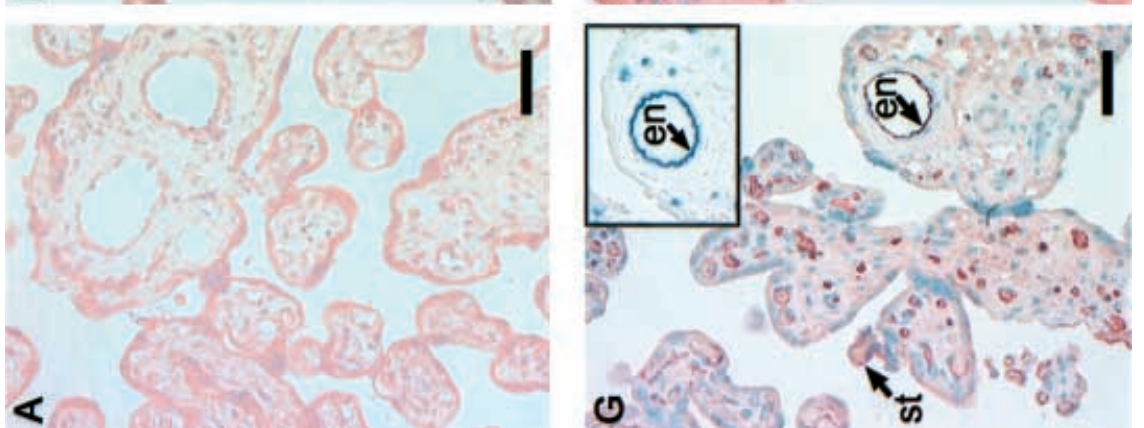
饭.

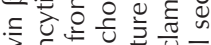

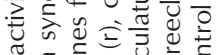

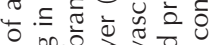

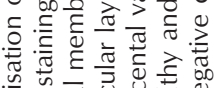

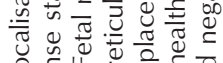
ง

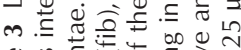

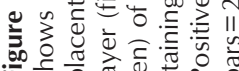




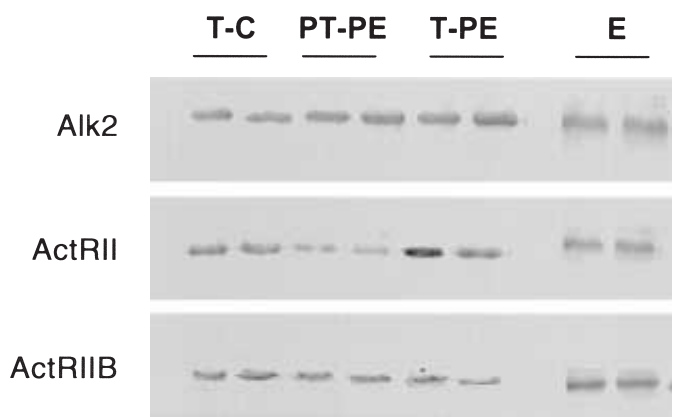

$68 \mathrm{KD}$

Figure 4 Western hybridisation; representative blots with placental, choriodecidual and amnion tissue protein (upper, mid and lower panels respectively) hybridised with activin receptor Alk2, ActRII and ActRIIB antibodies. Each blot contains proteins from T-C, PT-PE, T-PE and endometrium (E, positive control).

vessels of placental villi, and in serial placental sections these regions stained positively for the endothelial cell marker CD34 (Fig. 3G insert). In the fetal membranes, receptor Alk2, ActRII and ActRIIB proteins were detected in the fibroblast, reticular, chorionic trophoblast and adherent decidual cells and a few cells in the amniotic epithelium (Fig. 3I and J). The stroma of the positive control (endometrium) showed strong staining for activin receptors Alk2, ActRII and ActRIIB whereas staining was absent in the negative control sections (Fig. $3 \mathrm{~K}$ and $\mathrm{L}$ ).

Activin receptor proteins Alk2, ActRII and ActRIIB with estimated sizes of 68,62 and $60 \mathrm{kDa}$ respectively were detected in all healthy and preeclamptic gestational and endometrial tissues following Western hybridisation. Figure 4 shows representative blots probed with receptor Alk2, ActRII and ActRIIB antibodies. The relative amounts of activin receptor Alk2, ActRII and ActRIIB proteins in the placentae, amnion and choriodecidua from T-C, PT-PE and T-PE groups were compared by densitometry on Western blots except levels of receptor ActRII in amnion, where levels were too low for analysis (Fig. 5). Receptor Alk2 levels were significantly elevated in T-PE placenta $(P=0 \cdot 0006$, Mann-Whitney $U$ test $)$ whereas levels of receptor ActRIIB were significantly lower in PT-PE placenta $(P=0 \cdot 01)$ compared with controls. There were no significant differences in receptor Alk2 or ActRIIB levels in PT-PE, T-PE and healthy term amnion tissues. In the choriodecidua, receptor ActRII levels were significantly lower in PT-PE compared with normal $(P=0 \cdot 0002)$.

\section{Discussion}

Several recent studies have shown that maternal serum activin A levels are significantly elevated in women with established preeclampsia (Muttukrishna et al. 1997, 2000a, Silver et al. 1999, D'Antona et al. 2000). It is also accepted that the placenta is the major source of circulating activin
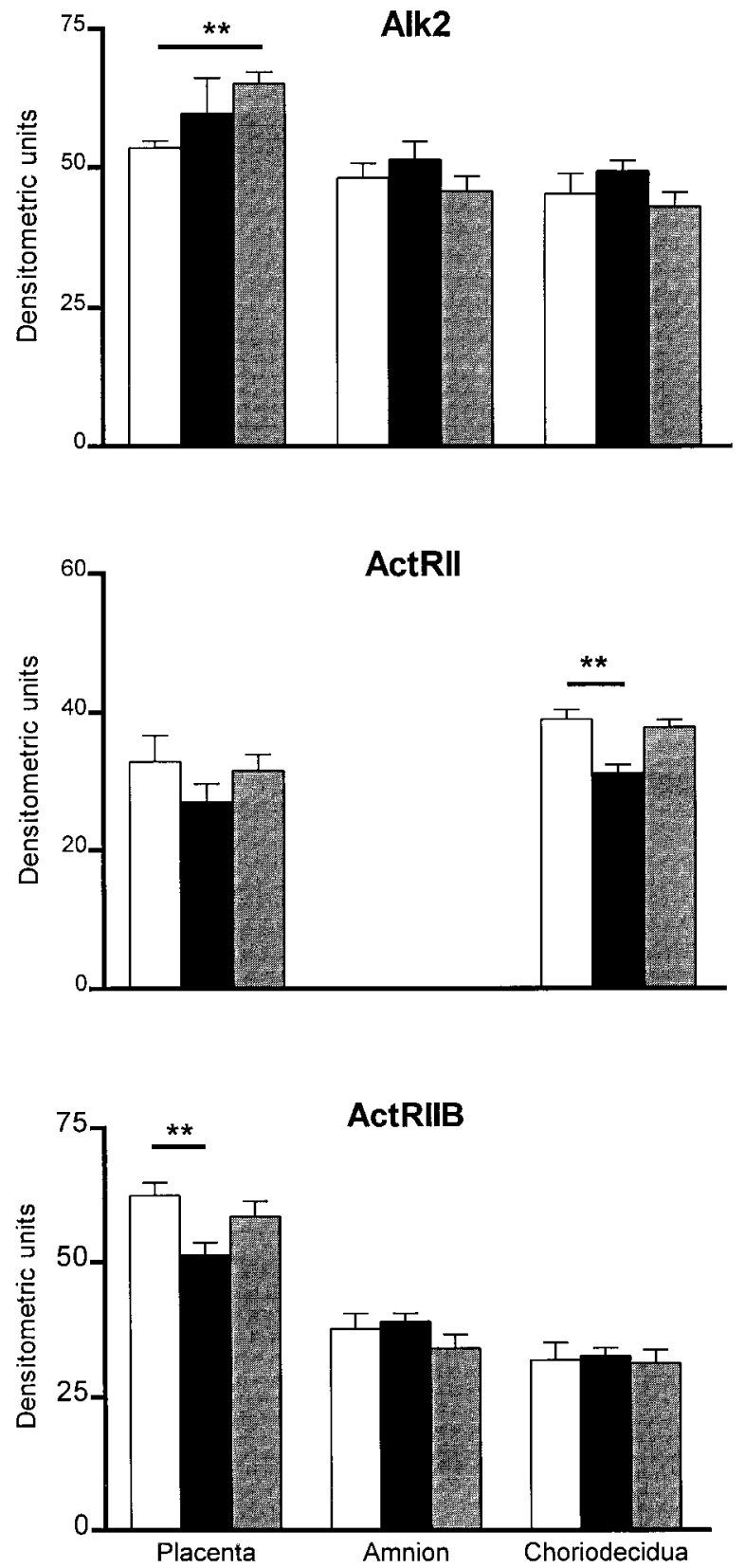

Figure 5 Semi-quantitation of activin receptor proteins; the relative receptor content in T-C (open bars), PT-PE (solid bars) and T-PE (shaded bars) tissue, expressed as the mean \pm S.E.M. of densitometric analyses of Western blots is shown. ${ }^{* *} P \leq 0 \cdot 01$ by Mann-Whitney $U$ test, $n=8-10$ per group.

in normal pregnancy (Wallace \& Healy 1996). In this study, we have shown that placental activin A production is increased in preeclampsia and that placental activin A content is highly correlated with maternal serum levels. Taken together, these data suggest that the elevated activin 
A levels observed in preeclampsia arise from the increased placental production.

However, preeclampsia is characterised by impaired renal function and we cannot exclude reduced renal clearance of activin A contributing to the increased circulating levels. On the other hand, the observation that maternal serum activin A levels are increased in early pregnancy, as early as 15 weeks of gestation, in women who are destined to develop preeclampsia (Muttukrishna et al. 2000a) and long before the onset of hypertension or renal involvement argues against impaired renal clearance as a major cause of the increased levels. Preeclampsia is also characterised by a systemic and intense inflammatory response (Redman et al. 1999) and it is therefore possible that activin A production by monocytes ( $\mathrm{Yu} \&$ Dolter 1997) may contribute to elevated circulating levels. Indeed, it has recently been shown that peripheral blood monocyte production of activin $\mathrm{A}$ is increased in preeclampsia (Muttukrishna et al. 2000b). However, we believe that it remains most likely that the majority of the increase in circulating activin A in preeclampsia is of placental origin, a belief supported by the correlation of serum activin A levels with placental activin A content.

The regulation of placental activin secretion and therefore the mechanisms underlying the increased production in preeclampsia remain poorly understood. The proinflammatory cytokines tumour necrosis factor- $\alpha$ (TNF $\alpha)$ and interleukin $1 \beta$ (IL-1 $\beta$ ) increase activin A synthesis in placental explant cultures derived from healthy pregnancies (Keelan et al. 1998). The observation that the preeclamptic placenta contains higher amounts of both cytokines (Conrad \& Benyo 1997) therefore offers a possible mechanism. However, physiological concentrations of activin A inhibit TNF $\alpha$ production in term placental explants (Keelan et al. 2000), suggesting that other factors may be involved. An alternative mechanism for elevated placental activin A synthesis could be hypoxaemia resulting from reduced intervillous blood flow in preeclampsia (Conrad \& Benyo 1997). Recent studies in the sheep have shown that acute foetoplacental hypoxia increases activin A levels and that levels fall rapidly with the return to normoxia (Jenkin et al. 2001). Whether this effect of hypoxia on activin $\mathrm{A}$ is direct or via other agents known to be hypoxia responsive such as TNF $\alpha$, IL-1 $\beta$ (Benyo et al. 1997) or hypoxia-inducible transcription factors remains unclear and worthy of further investigation.

Intriguingly, while placental production of activin A in preeclampsia is elevated, the content in the amnion and choriodecidua was significantly lower than normal, suggesting differential regulation in these tissues. Interestingly, based on studies of inhibins and activins in maternal serum and amniotic fluid from normal and Down's syndrome pregnancies, it has been suggested previously that placental and chorion trophoblast production of the $\beta_{\mathrm{A}}$ subunit may be differentially regulated (Wallace et al.
1997, 1999), a suggestion supported by the findings here. Nonetheless, these findings remain surprising because amniotic fluid TNF $\alpha$ levels are elevated in preeclampsia (Wang \& Walsh 1996) and TNFo increases activin A production from both normal amnion and choriodecidua in vitro (Keelan et al. 1998). Such studies of the fetal membranes derived from preeclamptic pregnancies would be worthwhile to explore whether differences in response to TNFa in vitro exist in comparison with normal tissue.

This study is the first to report the localisation of type I and type II activin receptor proteins in the placenta and fetal membranes and to explore if activin regulation in gestational tissue is altered in women with preeclampsia. Activin binds to ActRII or ActRIIB and the ligand receptor complex interacts with type I receptors Alk4 and possibly Alk2 leading to signal transduction (Attisano et al. 1996). In situ studies have localised activin receptor ActRII and ActRIIB mRNA to the syncytium and amniotic epithelium (Petraglia et al. 1994), consistent with the proposed roles for activin in both the regulation of placental secretion of various hormones, such as gonadotrophin hormone-releasing hormone, progesterone, human chorionic gonadotrophin (Petraglia et al. 1989, Song et al. 1996) and oestradiol (Ni et al. 2000), and in the onset of parturition, as suggested by inducing prostaglandin release by the fetal membranes (Petraglia et al. 1993b). However, we found only weak, sporadic receptor ActRIIB (also receptor Alk2 and ActRII) staining by immunohistochemistry in the trophoblast and amniotic epithelium which does not fully support a role for activin A in placental hormonogenesis or parturition in vivo in either healthy or preeclamptic women. This is consistent with the stable activin levels observed in the last weeks of pregnancy and during labour (Schneider-Kolsky et al. 2000). Of course, we have not studied the distribution of activin receptors in earlier pregnancy and an important role for activin in hormonogenesis cannot be excluded.

Most interestingly, we have found that all three activin receptor proteins are present in the endothelium of the placental vasculature. Type ActRII and ActRIIB mRNA have been shown to be expressed in adrenal capillary, pulmonary artery, aortic and human umbilical vein endothelial cells (HUVEC; McCarthy \& Bicknell 1993). Activin A inhibits HUVEC proliferation (McCarthy \& Bicknell 1993); however, activin mRNA expression is up-regulated in HUVECs in response to an atherogenic stimulus (de Waard et al. 1999) and activin A stabilises atherogenic plaques (Engelse et al. 1999). In contrast, follistatin, a specific activin-binding protein, stimulates HUVEC proliferation and angiogenesis (Kozian et al. 1997). However, follistatin levels in the maternal circulation are not significantly different in preeclamptic women (D'Antona et al. 2000). These observations are relevant here because preeclampsia is associated with systemic endothelial dysfunction (Redman et al. 1999), and it is possible that increased activin represents a 
response to endothelial injury, affording repair and stabilisation of a damaged endothelium. That activin is elevated in very early pregnancy prior to overt preeclampsia (Muttukrishna et al. 2000a) is still consistent with this hypothesis. In women who subsequently develop preeclampsia, there is some evidence of a hyperdynamic circulation in early pregnancy (Easterling \& Bernadetti 1989 ) and it is possible that this induces early pregnancy endothelial dysfunction.

In conclusion, we have found that placental activin A production is elevated in women with preeclampsia and that it may largely explain the elevation in the maternal circulation. Activin A and its receptor proteins are present in a number of cell types in the placenta and fetal membranes with no apparent differences in their distribution between preeclamptic and healthy tissue. However, receptor levels are altered in women with preeclampsia, suggesting that the paracrine and autocrine regulation could be altered.

\section{Acknowledgements}

We would like to thank the women who kindly agreed to participate in this study and the medical and nursing staff of the Monash Medical Centre. Funding for the study was provided by an Ella Macknight Fellowship to E M W from the Royal Australian and New Zealand College of Obstetricians and Gynaecologists.

\section{References}

Attisano L, Wrana JL, Montalvo E \& Massague J 1996 Activation and signalling by the activin receptor complex. Molecular and Cellular Biology 16 1066-1073.

Benyo DF, Miles TM \& Conrad KP 1997 Hypoxia stimulates cytokine production by villous explants from the human placenta. Journal of Clinical Endocrinology and Metabolism 82 1582-1588.

Conrad KP \& Benyo 1997 Placental cytokines and the pathogenesis of preeclampsia. American Journal of Reproductive Immunology 37 $240-249$.

D'Antona D, Reis FM, Benedetto C, Evans LW, Groome NP, de Krester DM, Wallace EM \& Petraglia F 2000 Increased maternal serum activin A but not follistatin levels in pregnant women with hypertensive disorders. Journal of Endocrinology 165 157-162.

Easterling TR \& Benedetti TJ 1989 Preeclampsia: a hyperdynamic model. American Journal of Obstetrics and Gynecology 160 1447-1453.

Engelse MA, Neele JM, van Achterberg TAE, van Aken BE, van Schaik RHN, Pannekoek H \& de Vries CJM 1999 Human activin $\mathrm{A}$ is expressed in the atherosclerotic lesion and promotes the contractile phenotype of smooth muscle cells. Circulation Research 85 931-939.

Fowler PA, Evans LW, Groome NP, Templeton A \& Knight PG 1998 A longitudinal study of maternal serum inhibin-A, activin-A, activin $-\mathrm{AB}$, pro- $\alpha \mathrm{C}$ and follistatin during pregnancy. Human Reproduction 13 3530-3536.

Jenkin G, Ward J, Hooper SB, O'Connor AE, de Krestser DM \& Wallace EM 2001 Feto-placental hypoxaemia regulated the release of fetal activin A and prostaglandin $\mathrm{E}_{2}$. Endocrinology 142 963-966.
Keelan JA, Groome NP \& Mitchell MD 1998 Regulation of activin A production by human amnion, decidua and placenta by proinflammatory cytokines. Placenta 19 426-423.

Keelan JA, Marvin KW, Sato TA, McCowan LME, Coleman M, Evans LW, Groome NP \& Mitchell MD 1999 Concentrations of activin A, inhibin A and follistatin in human amnion, choriodecidual and placental tissue at term and preterm. Journal of Endocrinology 163 99-106.

Keelan JA, Zhou RL \& Mitchell MD 2000 Activin A exerts both pro- and anti-inflammatory effects on human term gestational tissues. Placenta 21 38-43.

Knight PG, Muttukrishna S \& Groome NP 1996 Development and application of a two-site enzyme immunoassay for the determination of total activin A-concentrations in serum and follicular fluid. Journal of Endocrinology 148 267-279.

Kozian DH, Ziche M \& Augustin HG 1997 The activin-binding protein follistatin regulates autocrine endothelial cell activity and induces angiogenesis. Laboratory Investigations 76 267-276.

McCarthy SA \& Bicknell R 1993 Inhibition of vascular endothelial cell growth by activin-A. Journal of Biological Chemistry 268 23066-23071.

Massague J 1990 The transforming growth factor-beta family. Annual Reviews of Cell Biology 6 597-641.

Muttukrishna S, Knight PG, Groome NP, Redman CWG \& Ledger WL 1997 Activin A and inhibin A as possible endocrine markers for preeclampsia. Lancet 349 1285-1288.

Muttukrishna S, North RA, Morris J, Schellenberg JC, Taylor RS, Asselin J, Ledger W, Groome N \& Redman CWG 2000a Serum inhibin A and activin A are elevated prior to the onset of preeclampsia. Human Reproduction 15 1640-1645.

Muttukrishna S, Tannetta D, Groome N, Redman C \& Sargent I $2000 b$ Secretion of activin A by peripheral blood mononuclear cells (PBMCS) in culture and flowcytometric detection of intracytoplasmic inhibin/activin subunits and activin receptors. AresSerono Foundation Symposium 2, Melbourne, Australia, P45 (Abstract).

Ni X, Luo S, Minegishi T \& Peng C 2000 Activin A in JEG-3 cells: potential role as an autocrine regulator of steroidogenesis in humans. Biology of Reproduction 62 1224-1230.

Peng C, Ohno T, Koh LY, Chen VT \& Leung PC 1999 Human ovary and placenta express messenger RNA for multiple activin receptors. Life Sciences $64983-994$.

Perry IJ \& Beevers DG 1994 The definition of preeclampsia. British Journal of Obstetrics and Gynaecology 101 587-591.

Petraglia F, Vaughan J \& Wale W 1989 Inhibin and activin modulate the release of gonadotropin-releasing hormone, human chorionic gonadotropin, and progesterone from cultured human placental cells. PNAS 86 5114-5117.

Petraglia F, Garg S, Florio M, Sadick A, Gallinelli W, Wong W, Krummen L, Comitini G, Mather J \& Woodruff TK 1993a Activin $A$ and activin B measured in maternal serum, cord blood serum, and amniotic fluid during human pregnancy. Endocrinology Journal 1 323-327.

Petraglia F, Anceschi M, Calza L, Garuti GC, Fusaro P, Giardino I, Genazzani AR \& Vale W 1993 Inhibin and activin in human fetal membranes: evidence for a local effect on prostaglandin release. Journal of Clinical Endocrinology and Metabolism 77 542-548.

Petraglia F, Galinelli A, De Vita D, Lewis K, Methers L \& Vale W 1994 Activin at parturition: changes of maternal serum levels and evidence for binding sites in placenta and fetal membranes. Obstetrics and Gynecology 84 278-282.

Petraglia F, Di Blasio AM, Florio P, Gallo R, Genazzani AR, Woodruff TK \& Vale W 1997 High levels of fetal membrane activin $\beta A$ and activin ACTRIIB mRNAs and augmented concentrations of amniotic fluid activin $\mathrm{A}$ in women in term and preterm labor. Journal of Endocrinology 154 95-101.

Qu J \& Thomas K 1995 Inhibin and activin production in the human placenta. Endocrine Reviews 16 485-507. 
Rabinovici A, Goldsmith PC, Librach CL \& Jaffe RB 1992 Localization and regulation of activin-A dimer in human placental cells. Journal of Clinical Endocrinology and Metabolism 75 571-576.

Redman CWG, Sacks GP \& Sargent IL 1999 Preeclampsia, an excessive maternal inflammatory response to pregnancy. American Journal of Obstetrics and Gynecology 180 499-506.

Riley SC, Balfour CM, Wathen N, Chard T, Evans LW, Groome NP \& Wallace EM 1998 Follistatin and activin A in extra-embryonic ceolomic and amniotic fluids and maternal serum in early pregnancy. Human Reproduction 13 2624-2628.

Schneider-Kolsky M, D'Antona D, Evans L, Taylor N, O'Connor A Groome NP, de Kretser D \& Wallace EM 2000 Maternal serum total activin A and follistatin in pregnancy and parturition. British Journal of Obstetrics and Gynaecology 107 995-1000.

Silver HM, Lambert-Messerlian GM, Star JA, Hogan J \& Canick JA 1999 Comparison of maternal serum total activin A and inhibin A in normal, preeclamptic, and nonproteinuric gestationally hypertensive pregnancies. American Journal of Obstetrics and Gynecology 180 1131-1137.

Song Y, Keelan JA \& France JY 1996 Activin A stimulates, while transforming growth factor beta 1 inhibits, chorionic gonadotrophin production and aromatase activity in cultured human placental trophoblasts. Placenta 17 603-610.

de Waard V, van den Berg BM, Veken J, Schultz-Heienbrok R, Pannekoek H \& Zonneveld AJ 1999 Serial analysis of gene expression to assess the endothelial cell response to an atherogenic stimulus. Gene 226 1-8.

Wallace EM \& Healy DL 1996 Inhibins and activins: roles in clinical practice. British Journal of Obstetrics and Gynaecology 103 945956.

Wallace EM, Crossley JA, Groome NP \& Aitken DA 1997 Inhibin-A in amniotic fluid in chromosomally normal and Down's syndrome pregnancies. Journal of Endocrinology 152 109-112.

Wallace EM, D'Antona D, Shearing C, Evans LW, Thirunavukarasu P, Ashby JP, Shades M \& Groome NP 1999 Amniotic fluid levels of dimeric inhibins, pro- $\alpha \mathrm{C}$ inhibins, activin $\mathrm{A}$ and follistatin in Down's syndrome. Clinical Endocrinology 50 699-673.

Wang YP \& Walsh SW 1996 TNF- $\alpha$ concentrations and mRNA expression are increased in preeclamptic placentas. Journal of Reproductive Immunology 32 157-163.

Ying S, Zhang Z, Furst B, Batres Y, Huang G \& Li G 1997 Activins and activin receptors in cell growth. Proceedings of the Society for Experimental Biology and Medicine 214 114-122.

Yu J \& Dolter KE 1997 Production of activin A and its roles in inflammation and hematopoiesis. Cytokines, Cellular and Molecular Therapies 3 169-177.

Received in final form 7 June 2001

Accepted 26 June 2001 